\title{
FIFTY YEARS OF THE HYPOTELMINORHEIC: WHAT HAVE WE LEARNED?
}

\author{
PETDESET LET HIPOTELMINOREJIKA: \\ KAJ SMO SE NAUČILI?
}

\author{
Tanja PIPAN ${ }^{1}$, Cene FIŠER ${ }^{2}$, Tone NOVAK ${ }^{3} \&$ David C. CULVER ${ }^{4}$
}

\begin{abstract}
UDC 574.2:556.3

Tanja Pipan, Cene Fišer, Tone Novak \& David C. Culver: Fifty Years of the Hypotelminorheic: What Have We Learned?

Originally described by Meštrov in 1962, hypotelminorheic habitats are superficial subterranean drainages, typically less than a meter or so in depth, that emerge at small seepage springs. These are persistent wet spots, typically with blackened leaves in small depressions. There may be no flow during dry periods, but the underlying clay retains water above. They share the landscape with other small bodies of water (močila in Slovenian), not necessarily connected with groundwater. Hypotelminorheic habitats (mezišča in Slovenian) usually harbor a fauna dominated by species adapted to subterranean life, characteristically without eyes or pigment. The basic chemistry and hydrology of the habitat is described as are the basic faunal elements. The habitat is placed in a more general context by reviewing how species invade the habitat, their morphology, and their possible connection to deeper subterranean habitats.

Keywords: hypotelminorheic, seepage spring, stygobionts, Milan Meštrov.
\end{abstract}

\begin{abstract}
Izvleček UDK 574.2:556.3
Tanja Pipan, Cene Fišer, Tone Novak \& David C. Culver: Petdeset let hipotelminorejika: Kaj smo se naučili?

Hipotelminorejične habitate, kratko hipotelminorejik, je opisal Milan Meštrov leta 1962. Tvorijo jih šibki podzemeljski vodni tokovi tik pod površjem, običajno do globine enega metra. Za trajno mokra mesta je značilno počrnelo listje $\mathrm{v}$ manjših talnih vdolbinah. V sušnih obdobjih lahko tanek tok vode preneha, vendar se voda zadržuje nad glinenim dnom močila. Te vode primezijo na površje v drobnih izvirih; od tod slovensko ime mezišča za te habitate. Stik s talno vodo razmejuje mezišča od drugih majhnih vodnih teles, t. i., močil, ki lahko nastanejo tudi na druge načine. Običajno so za favno mezišč značilne vrste, ki so prilagojene na življenje v podzemeljskih habitatih in so praviloma brez oči ali pigmenta. V članku so opisane osnovne kemijske in hidrološke značilnosti mezišč ter navedeni osnovni predstavniki njihove favne. Habitati so predstavljeni nekoliko širše s pregledom možnosti njihove poselitve, morfoloških značilnosti vrst ter možnih povezav z globljimi podzemeljskimi habitati.

Ključne besede: hipotelminorejik, mezišče, močilo, stigobionti, Milan Meštrov.
\end{abstract}

\section{INTRODUCTION}

The shallowest of groundwater habitats, defining groundwater in the sense of water under the surface not exposed to light, can occur less than a meter beneath the ground. There exist miniature shallow subterranean catchments, often draining less than $1000 \mathrm{~m}^{2}$ and rarely more than $10,000 \mathrm{~m}^{2}$ (Culver, Pipan \& Gottstein 2006). The Croatian speleobiologist, Milan Meštrov (1929-2010) applied the term "hypotelminorheic" to shallow groundwater habi-

\footnotetext{
${ }^{1}$ Karst Research Institute ZRC SAZU, Titov trg 2, SI-6230 Postojna, Slovenia, e-mail: pipan@zrc-sazu.si

${ }^{2}$ Department of Biology, Biotechnical Faculty, University of Ljubljana, Večna pot 111, SI-1000 Ljubljana, Slovenia, e-mail: cene.fiser@bf.uni-lj.si

${ }^{3}$ Department of Biology, Faculty of Natural Sciences and Mathematics, University of Maribor, Koroška 160, SI-2000, Maribor, Slovenia, e-mail: tone.novak@uni-mb.si

${ }^{4}$ Department of Environmental Science, American University, 4400 Massachusetts Ave. NW, Washington, D.C. 20016 U.S.A., e-mail: dculver@american.edu
}

Received/Prejeto: 11.10 .2012 
tats that are vertically isolated from the water table and are "constituted of humid soils in the mountains, rich in organic matter and traversed by moving water" (Meštrov 1962, 1964). He provided a rather general description of the habitat, and included cases where the habitat was in close proximity to caves (he gave an example from Moulis, France) and an example of where the outlet of a hypotelminorheic habitat was the beginning of a mountain stream in Risnjak, Croatia. His interest in the hypotelminorheic was primarily biological, and he discovered that the fauna of hypotelminorheic habitats included surface-dwelling species, species primarily found in caves, and most interestingly, species specialized for the hypotelminorheic. Reading the original description of habitat that he published in Comptes Rendus de l'Académie des Sciences, Paris in 1962, one realizes that he felt that he was really on to the something. He indicated that it could be a dispersal corridor because he thought the habitat was widespread, that it could harbor a unique fauna specialized for the habitat, and that it could be a "staging area" for the colonization of caves. A sketch of one of his study sites on Medvednica Mountain near Zagreb is shown in Fig. 1.

The hypotelminorheic habitat has been intermittently studied since its initial discovery (Lattinger 1988).

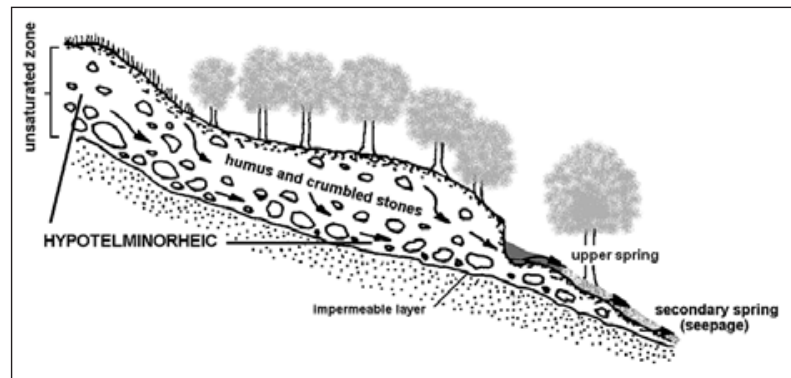

Fig. 1: Sketch of hypotelminorheic habitat by Gottstein Matočec et al. (2002), slightly modified.

Meštrov did not write anything further about the habitat. In USA, the study of hypotelminorheic habitats was tak- en up in the mid-1960's, due to the impetus of Holsinger (e.g., Holsinger 1978). An astonishing total of five species of the amphipod genus Stygobromus were found in Rock Creek Park (Culver \& Šereg 2004; Pavek 2002), signaling that a rich, interesting fauna was present in these little-studied small habitats. In Slovenia, the study of hypotelminorheic habitats did not begin in earnest until 2006, with the start of the study of hypotelminorheic habitats on Nanos Mountain (Culver et al. 2006).

In fact, the hypotelminorheic has usually been ignored in overall groundwater classification schemes (e.g., Hahn 2009). Juberthie (2000) included it in his discussion of subterranean habitats, but more as a special case than as an integral part of the subterranean realm. The very non-euphonious nature of the word (Greek roots expressed in French by a Croatian biologist) has even led to ridicule (Chapman 1993), but the authors of this review believe that the term is useful, especially in the context of shallow subterranean habitats in general (Culver et al. 2006; Culver \& Pipan 2008, 2011; Fišer et al. 2010).

It has been fifty years since Meštrov's original publication, and it offers a time marker to take stock of the hypotelminorheic. We first refine the definition of the hypotelminorheic, put it in a hydrological context, and briefly describe some representative hypotelminorheic habitats, especially in Slovenia. Next we review the chemical and physical conditions of the hypotelminorheic. Especially interesting in this regard is whether Meštrov was correct in his claim that the hypotelminorheic was a subterranean habitat relatively rich in organic carbon. Third, we review the species composition, species richness, and ecology of the hypotelminorheic fauna, and assess Meštrov's hypothesis that there were three components surface species, cave stygobionts (species limited to subterranean habitats), and hypotelminorheic specialists. Finally, we try to place the hypotelminorheic in a more general ecological and evolutionary context, by raising a series of general questions about the hypotelminorheic.

\section{THE HYPOTELMINORHEIC DESCRIBED AND DEFINED}

As with any subterranean catchment, water exits in springs, which take a wide variety of forms (Kresic 2010). Because springs provide access to these habitats, although indirectly, they are often the only places where the groundwater fauna can be sampled, and this is especially true for the miniaturized hypotelminorheic basins and their exits. The emergence points of water from the hypotelminorheic have been given a series of names, none of them entirely satisfactory, and this has resulted in continuing terminological confusion. Perhaps the earliest name used was "seep" (e.g., Holsinger 1967), but this term, in American usage at least, often refers to petroleum oozing out of the ground. Less confusing is the term "seepage spring." According to Kresic (2010), a 
seepage spring is a diffuse discharge of water, when the flow cannot be immediately observed but the land surface is wet compared to the surrounding area. Kresic also provides a useful context for the classification of seepage springs within the general framework of springs. Flows of seepage springs are typically less than $10 \mathrm{~cm}^{3}$ per second, making them eighth order springs in Kresic's extension of Meinzer's (1923) categorization of springs by their discharge rate. Seepage springs are gravity fed and situated in sediment. Kresic (2010) pointed out that variability of discharge is an important hydrological and ecological parameter, and indicated that if the ratio of the maximum to minimum discharge exceeds 10 , then the spring can be considered highly variable. Because many seepage springs have little or no flow during hot, dry periods, they would be classified as highly variable.

For most species associated with the hypotelminorheic, it is the subterranean water of the hypotelminorheic and not the seepage spring, i.e., the groundwater/surface water ecotone (see Gibert 1991), that is their primary habitat. The seepage spring is the point of collecting most of the hypotelminorheic fauna, although is not the shallow groundwater habitat itself, but a few species are primarily inhabitants of the ecotone itself (see below). The hypotelminorheic and the ecotone are clearly an example of a groundwater dependent ecosystem (Eamus \& Froend 2006). Seepage springs are also isolated wetlands, although a highly miniaturized ones.

An even more basic problem, when trying to locate seepage springs in the field, is whether a wet spot in the woods is in fact a seepage spring at all. Small superficial water bodies may be extremely temporary basins for recent precipitation, or they may be basins that retain precipitation for extended periods of time. Small vernal pools, a familiar habitat in many temperate woodlands, especially in glaciated areas (Keeley \& Zedler 1998), can be mistaken for a hypotelminorheic habitat in the absence of chemical or biological analysis. In this context, two Slovenian terms may be useful to distinguish a seepage spring (mezišče) from a wet spot in natural areas whatever its provenance (močilo).

Elaborating on Meštrov's (1962) definition, Culver et al. (2006) proposed that the term "hypotelminorheic" be used to describe habitats with the following major features (see also Culver \& Pipan 2008):

1. A perched aquifer fed by subsurface water that creates a persistent wet spot

2. Underlain by a clay or other impermeable layer typically 5 to $50 \mathrm{~cm}$ below the ground surface

3. Rich in organic matter compared with other aquatic subterranean habitats.

Culver et al. (2006) also indicated that the drainage area of a seepage spring is typically less than $1 \mathrm{ha}$, in a shallow depression, and that the leaves in the seepage spring are characteristically blackened and not skeletonized. Without a clay layer, water should tend to move vertically, and there would be no persistent water. The

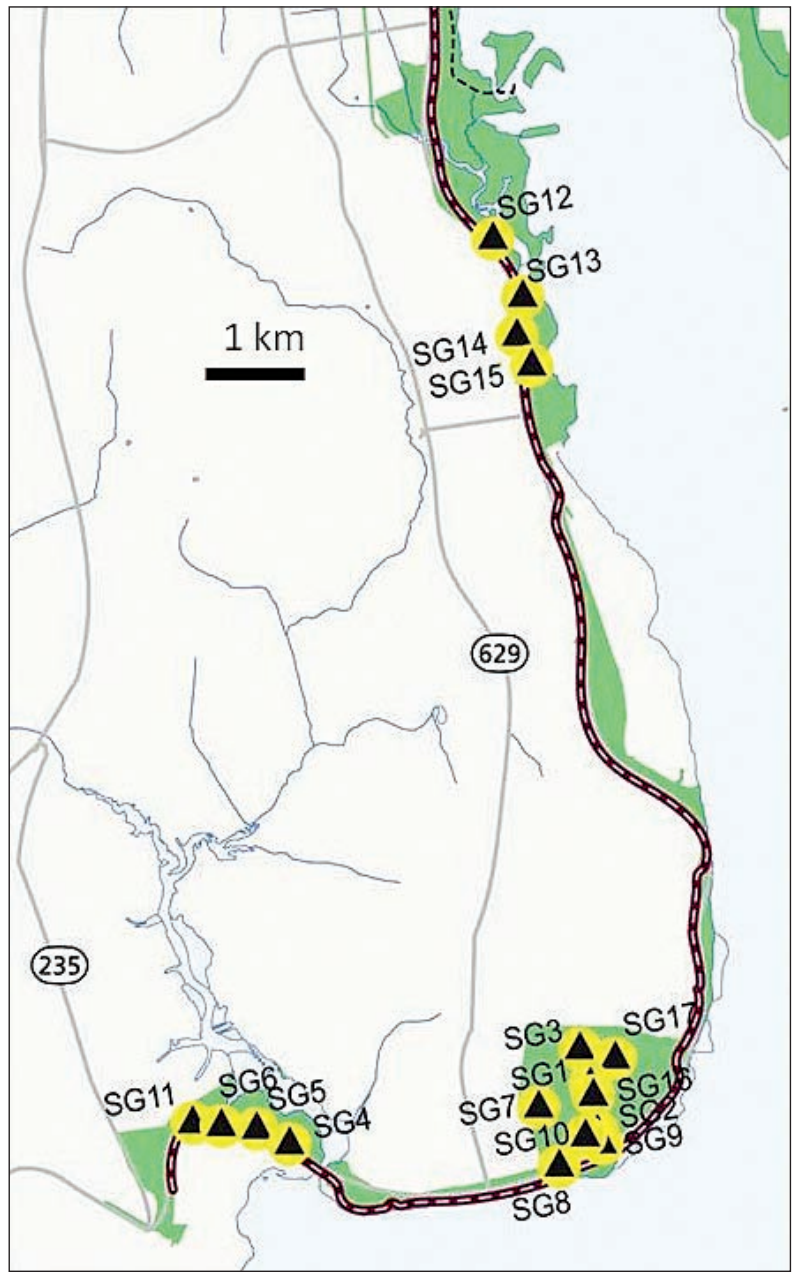

Fig. 2: Map of southern section of George Washington Memorial Parkway near Washington, DC, USA, showing the locations of seepage springs.

water exits at a seepage spring, although there may not be flow at all times during the year.

Clay is a critical component of hypotelminorheic habitats, not only because it acts as a barrier to the downward movement of water, but also because during periods of drought, the water retained by the colloidal clay may serve as a refuge for invertebrates in the hypotelminorheic, into which they can burrow (Holsinger \& Dickson 1977). According to Ginet and Decu (1977), clay may also have some nutritional value for subterranean crustaceans.

Because of its miniature size, most of the standard tools employed by groundwater hydrologists to measure 

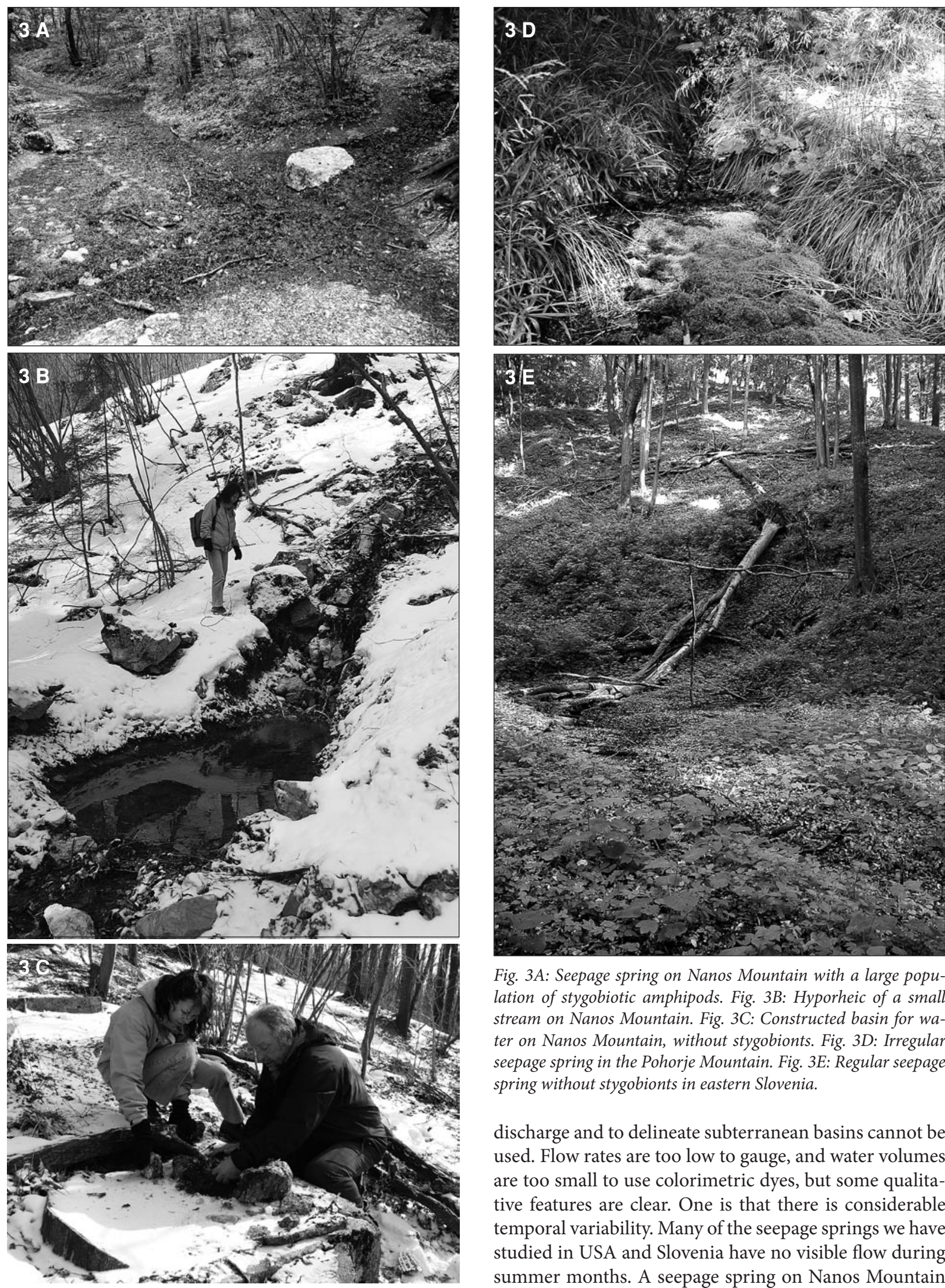

Fig. 3A: Seepage spring on Nanos Mountain with a large population of stygobiotic amphipods. Fig. 3B: Hyporheic of a small stream on Nanos Mountain. Fig. 3C: Constructed basin for water on Nanos Mountain, without stygobionts. Fig. 3D: Irregular seepage spring in the Pohorje Mountain. Fig. 3E: Regular seepage spring without stygobionts in eastern Slovenia.

discharge and to delineate subterranean basins cannot be used. Flow rates are too low to gauge, and water volumes are too small to use colorimetric dyes, but some qualitative features are clear. One is that there is considerable temporal variability. Many of the seepage springs we have studied in USA and Slovenia have no visible flow during summer months. A seepage spring on Nanos Mountain 
had no visible flow or even moisture for a period of nearly a year, but began to flow again in 2012, with species specialized for the hypotelminorheic reappearing in the seepage spring. A new seepage spring also appeared, apparently the result of habitat alteration by wild animals, probably boar. Likewise, Fong (pers. comm.) observed a seepage spring in Pimmitt Run in George Washington Memorial Parkway in Virginia (USA) migrate down slope about $2 \mathrm{~m}$ after a dry period. Given the very superficial nature of both the hypotelminorheic and its seepage spring, this kind of observation is not surprising. There are also times of intense precipitation that may hydrologically connect seepage springs with above ground flow, i.e., sheet flow, especially since seepage springs are clustered geographically (Fig. 2).

Hypotelminorheic and other shallow subterranean habitats can have a variety of physical appearances, and we review those occurring in Slovenia as an example of the range of such habitats. The typical hypotelminorheic habitat, one that we have studied in Croatia, Slovenia, and USA (Culver et al. 2006) has a characteristic aspect. There is a subtle flattening of the landscape, often with a small depression. At most times water is not visible but the blackened leaves of the seepage spring are (Fig. 3A). Other shallow subterranean habitats present include somewhat larger, more permanent springs with visible flow for most or all of the year (Fig. 3B), but neither hypotelminorheic specialists nor the blackened leaves of seepage springs are present. We suspect that the presence of blackened leaves indicates that shredding invertebrate feeders, such as the amphipod Synurella ambulans, are not present. A third habitat type on Nanos Mountain are small headwater springs that emerge from tubes in dirt with diameters typically of less than $10 \mathrm{~cm}$, which Kresic (2010) calls gushets. Active only at times of high runoff, they nonetheless can harbor hypotelminorheic species, probably that have been flushed out of hypotelminorheic habitats by high water. A fourth habitat present on Nanos Mountain (Fig. 3C) is representative of a class of anthropogenically created shallow subterranean habitats. This small concrete lined basin, probably constructed as a water source for farm animals, holds water year round although it can be frozen solid in winter. This particular site contained no stygobionts or other macroinvertebrates, but other such habitats do, especially the outlet for drained field (tiled fields) (Culver, Holsinger \& Feller 2012). Fišer et al. (2007) studied a very different kind of very shallow subterranean habitat that was inhabited by stygobiotic Niphargus. The stream Kolaški potok in southwest Slovenia rises, sinks and rises again over a distance of approximately $500 \mathrm{~m}$. The depth of the $150 \mathrm{~m}$ long underground portion is not known but it is probably less than one or two meters. The stream itself is perched on top of a layer of granulated substrate of clay, marl, flattened stones, and organic debris. The primary geological formations in the area are silicate-clay rich sediments in sandy marl layers in flysch. Sivec (1982) described a wingless plecopteran species that inhabits a hypotelminorheic like habitat on the Pohorje Mountain (Fig. 3D). Such places most commonly appear in the contact zones between various metamorphic, non-carbonate rocks, like schists, gneiss and diaphthorite (phyllonite) in altitudes of over $1000 \mathrm{~m}$. These habitats may have flows greater than $1 \mathrm{~L} / \mathrm{sec}$ but reduce to a few isolated wet patches in dry weather. Spring dwelling species, but no stygobionts, have been found in this habitat, likely because none is known in this region. Another interesting anthropogenic hypotelminorheic like habitat has been located in northeast Slovenia in front of an abandoned shallow mine in conglomerate and sandstone (Fig. 3E). This habitat contained typical spring dwelling species but no stygobionts. Nonetheless, stygobiotic Niphargus living in puddles of tiny water influx at the end of the mine indicates that such water fluxes might mimic a typical hypotelminorheic habitat.

While only Slovenian, Croatian, French, and United States hypotelminorheic habitats have been identified and studied, they are likely widespread, at least throughout the temperate zone. The basic requirements for the presence of hypotelminorheic habitats of sufficient rainfall and the presence of a clay layer are conditions that are certainly met in many regions.

\section{PHYSICO-CHEMISTRY OF THE HYPOTELMINORHEIC}

Temperature and some basic chemical water measurements are available for three hypotelminorheic sites George Washington Memorial Parkway, Medvednica Mountain, and Nanos Mountain (Tab. 1). Average temperatures vary considerably from site to site. The temperature of groundwater approximates the mean annual temperature (assuming it is not thermal water), and the differences in Tab. 1 reflect this. Both $\mathrm{pH}$ and conductivity are consistent from site to site $-\mathrm{pH}$ is near 7.0 and conductivity is moderately high, around $350 \mu \mathrm{S} / \mathrm{cm}$. The moderately high conductivity indicates that water has been retained underground for some period of time (or 
Tab.1: Comparison of chemical parameters (means only) at three hypotelminorheic sites with stygobiotic amphipods. Data from Culver et al. (2006).

\begin{tabular}{l|c|c|c|c}
\hline Site & Temperature $\left({ }^{\circ} \mathrm{C}\right)$ & $\mathrm{pH}$ & Conductivity $(\mu \mathrm{S} / \mathrm{cm})$ & Dissolved Oxygen $(\mathrm{mg} / \mathrm{L})$ \\
\hline George Washington Memorial Parkway & 16.1 & 6.56 & 336 & 6.22 \\
\hline Medvednica Mountain & 7.3 & 7.14 & 384 & 9.37 \\
\hline Nanos Mountain & 7.1 & 7.32 & 365 & 4.97 \\
\hline
\end{tabular}

evaporating on the surface, an unlikely scenario). Dissolved oxygen values also varied, perhaps because of temperature differences and different amounts of decaying organic matter in the habitat.

A nearly 18 month hourly record of conductivity and temperature from a seepage spring on Nanos Mountain provided additional insight into the complex pattern of the hypotelminorheic. A datalogger, placed under a $20 \mathrm{~cm}$ thick rock at a site of a seepage spring with stygobionts (Niphargus stygius), showed a pattern of increasing temperature and conductivity from March 2011 to August 2011 (Fig. 4). During this period, the two

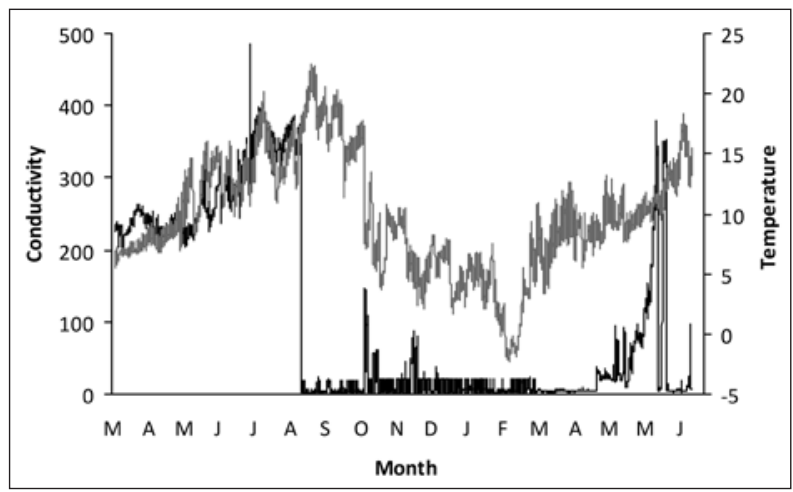

Fig. 4: Hourly temperature (gray line) and conductivity (black line) from 10 March 2011 to 10 July 2012 for a seepage spring on Nanos Mountain, Slovenia.

parameters were strongly correlated $(\mathrm{r}=0.82, \mathrm{p}<.001)$, although temperature showed more variability. In addition, both showed a 24 hour cycle of variation. The rise in water temperature paralleled the rise in air temperature (from approximately $5.5^{\circ} \mathrm{C}$ to $20.2^{\circ} \mathrm{C}$ ) during the summer months, and the rise in conductivity (from approximately $220 \mu \mathrm{S} / \mathrm{cm}$ to $370 \mu \mathrm{S} / \mathrm{cm}$ ) was likely the result of increased residence time of water in the subsurface. On 14 August, 2011 at 4PM, conductivity fell from $376 \mu \mathrm{S} / \mathrm{cm}$ to $27 \mu \mathrm{S} / \mathrm{cm}$, caused by drying of the habitat. Until 25 April, 2012 the site was dry, and then conductivity slowly began to rise, indicating re-wetting. Amphipods were present by May 20, 2012, and the site experienced periodic wetting and drying until the datalogger was removed on 10 July, 2012. As the site dries, the animals must move to water or burrow into clay to avoid desiccation. Although less variable than surface waters, this is a highly variable subterranean habitat, one with stygobionts.

In a study of basic physical and chemical parameters of more than 70 putative hypotelminorheic sites in the George Washington Memorial Parkway (see Fig. 2), Culver and Chesnut (2006) found that sites with the stygobiotic genus Stygobromus were significantly colder (the study was done in spring and summer), with more dissolved oxygen, lower $\mathrm{pH}$, and lower $\mathrm{NO}_{3}^{-}$. The occurrence of Stygobromus in water with lower nitrate levels may indicate negative impacts of anthropogenic sources of nitrate. Conductivity was higher at Stygobromus sites, but not significantly so.

Much of the organic carbon available in the seepage spring is likely in the form of particulate organic carbon, decaying leaves in particular. Particulate organic carbon is may be less common in the hypotelminorheic itself, as the water there has been at least partially filtered by the soil. Information on dissolved organic carbon levels in seepage springs with stygobiotic amphipods, without them, and in small springs and a hyporheic site is available for some sites on Nanos Mountain (Fig. 5).

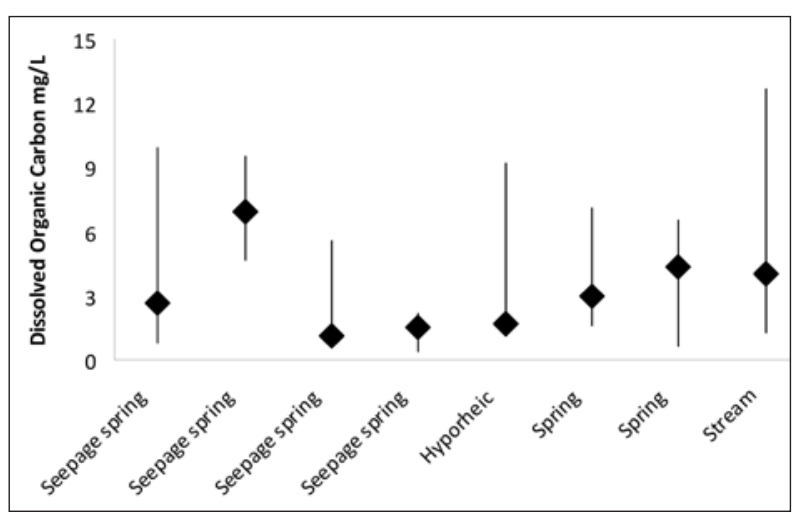

Fig. 5: Dissolved organic carbon $(\mathrm{mg} / \mathrm{L})$ for seepage springs, small springs, and hyporheic sites on Nanos Mountain, Slovenia.

Dissolved organic carbon levels in all four habitats were quite variable, the result of the very superficial nature of the habitats with close connections with the surface. We do not know what caused the spikes in organic carbon in any of the sites, but wild boars and cattle have been occasionally observed and the highest levels of organic carbon may be the result of their presence. The sites with dense populations of the stygobiotic amphipods 
Niphargus stygius and N. tamaninii displayed the highest average dissolved organic carbon concentration (4.52 $\mathrm{mg} / \mathrm{L}$ ), while the lowest concentrations were observed in seepage springs with no stygobiotic amphipods and few other invertebrates. Intermediate values of dissolved organic carbon were present in small springs dominated by surface-dwelling species and in the hyporheic habitat of a small stream. These data are tantalizing in hinting at an apparent connection between organic carbon and the presence of stygobionts. This would be an important starting point for further inquiry.

We suggest that an operational definition of a hypotelminorheic habitat is one where one or more species with reduced eyes and pigment is found, a characteristic of most hypotelminorheic specialists (Culver \& Pipan 2011).

\section{THE FAUNA}

In a biogeographic study of the lower Potomac basin, Culver and Pipan (2008) found that a total of 15 crustaceans and molluscs were common in seepage springs (Tab. 2). Five of these species were habitat specialists, found only itself rather than the groundwater (Fong \& Kavanaugh 2010).

As is true for stygobiotic species in general, the geographic ranges of hypotelminorheic species are small, and even within their ranges, habitat occupancy is low. For example, the amphipod Stygobromus caecilius is known from a single seepage spring, and S. foliatus is known from five widely dispersed seepage springs up to $100 \mathrm{~km}$ apart (Culver et al. 2012). There are a few widespread species which have high habitat occupancy within their range. The two subspecies of Stygobromus tenuis each range over several hundred $\mathrm{km}$, and are found in hundreds of sites.

Reliable estimates of species richness of hypotelminorheic habitats are especially difficult to obtain both because of the difficulties of collecting, which can in the hypotelminorheic habitats, and two were found in other subterranean habitats as well. Six species were stygophile (species that can complete their life cycle in both surface and subterranean aquatic habitats), and two were occasional inhabitants that may infrequently establish breeding populations in the hypotelminorheic, perhaps dispersing into the habitat during times of flood. For nearly all of these species, it is likely the hypotelminorheic and not the seepage spring itself that is their primary habitat if for no other reason than their appearance only at times of flowing water. However, the stygobiotic isopod Caecidotea kenki, is concentrated in the ecotone often only be done in springtime, and because of the very local differences in species composition among seepage springs. In a $5 \mathrm{~km}$ long section of Rock Creek Park, seven seepage springs were intensively and repeatedly sampled. The species accumulation curve (Fig. 6) reached an asymptote of four species of Stygobromus after an average of four seepage springs were sampled. There are no data available that indicate how many times a given seepage spring needs to be sampled, but at least in the lower Potomac basin, sampling outside of springtime, when discharge rates are high, is unproductive (Culver \& Šereg 2004). 
Fišer et al. (2010) have done the only study to date about niche separation of different species living in the hypotelminorheic. They investigated the co-occurrence and water chemistry of two species of Niphargus that are often found in hypotelminorheic habitats. Both species - N. sphagnicolus and N. slovenicus - occur not only in hypotelminorheic habitats, but have also been found in surface waters associated with groundwater. For example, the type locality of N. slovenicus is a forest ditch near the city of Kranj, Slovenia, and the type locality of $N$. sphagnicolus a small Sphagnetum wetland in the middle of Ljubljana, the capital of Slovenia. Both of these habitats are likely groundwater fed. They investigated the two

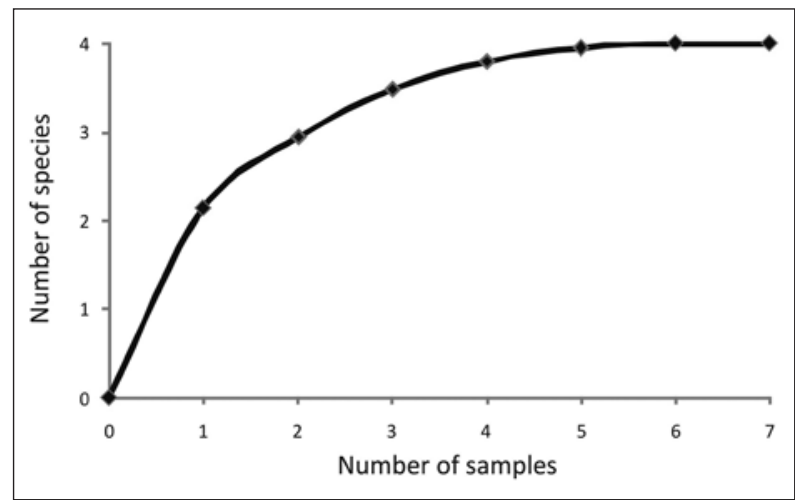

Fig. 6: Species accumulation curve, based on 50 randomly drawn samples, of the amphipod fauna of seven seepage springs in Rock Creek Park, Washington, D.C. (USA). From Culver and Pipan (2011).

Niphargus species by examining 65 grids $3 X 5 \mathrm{~km}$ in size in the alluvial plain of the Sava River between Kranj and Ljubljana. In each grid, a seepage spring and spring were sampled, although not all grids had both habitats. Of the 110 sites examined, 19 were inhabited by $N$. slovenicus and 17 by $N$. sphagnicolus. Neither species showed a preference for seepage springs or for springs, and were found in nearly the same number of springs and seepage springs. However, they never co-occurred, even though they were often found in nearby sites. Fišer et al. (2010) found differences in $\mathrm{pH}$, oxygen concentration, and conductivity, but not temperature between the sites with the two species. N. slovenicus is confined to more basic and more oxygenated waters, while N. sphagnicolus is found in more acidic, less oxygenated waters. An important point to emerge from their study is that not all seepage springs are identical, nor can they be expected to harbor the same species.

Fong and Kavanaugh (2010, and unpublished) studied the relationship between temperature and abundance of two species found in a seepage spring along Pimmitt's Run in the George Washington Memorial Parkway in
Virginia, USA. The eyeless and depigmented amphipod Stygobromus tenuis potomacus, and pigmented and small-eyed isopod Caecidotea kenki are common in many seepage springs in the area, but their abundances with respect to temperature are quite different (Fig. 7). Styogobromus tenuis potomacus abundance shows a strong, significantly negative relationship with temperature, in-

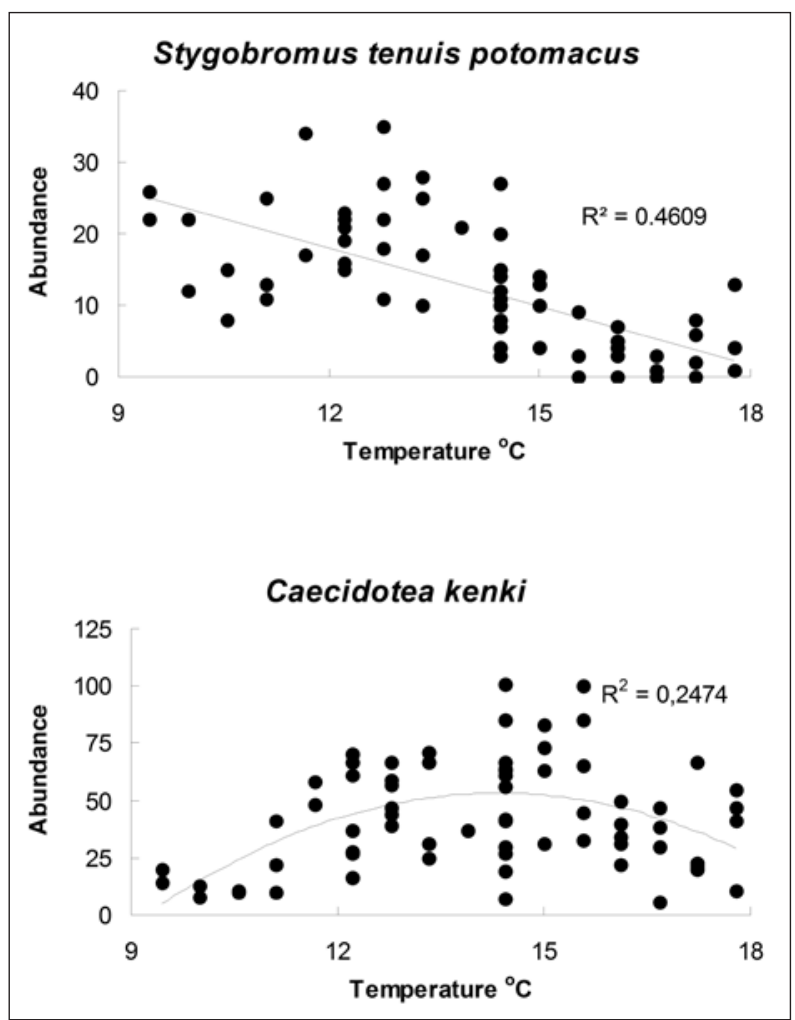

Fig. 7: Graphs showing relationship between water temperature and abundance of Stygobromus tenuis potomacus and Caecidotea kenki in Pimmitts Run, George Washington Memorial Parkway, Virginia. For S. tenuis potomacus, the quadratic term was not significant, but the linear term was $(p<.001)$ and accounted for 46 percent of the variance in abundance. For $C$. kenki, the quadratic term was significant $(p<.001)$, and accounted for 24 percent of the variance in abundance. Data from Fong and $\mathrm{Ka}$ vanaugh (unpublished), used with permission.

dicating that it prefers cooler temperatures. The lowest temperature recorded in the seepage spring was $9.4^{\circ} \mathrm{C}$, and it is possible that if seepage spring temperature gets colder than this, that $S$. tenuis potomacus would retreat back into the hypotelminorheic. When temperatures in the seepage spring were low, $S$. tenuis potomacus moved out of the hypotelminorheic into the relatively nutrient rich seepage spring. It is possible that if seepage spring temperature gets warmer, individuals would retreat back into the hypotelminorheic. By contrast, C. kenki shows a quadratic relationship, with a maximum abundance at 
$14^{\circ} \mathrm{C}$. This is consistent with the hypothesis that C. kenki inhabits the seepage spring itself rather than the associated hypotelminorheic, which will often be colder. The mean annual temperature of hypotelminorheic water should be close to $12.1^{\circ} \mathrm{C}$, the mean annual air temperature of Washington, D.C. In spite of this microhabitat difference, both are part of the obligate fauna of aquatic SSHs. As was the case for the study of Fišer et al. (2010), inhabitants of seepage springs and the hypotelminorheic clearly showed microhabitat separation.

Little studied is the terrestrial fauna that inhabits the non-aqueous parts of the hypotelminorheic and seepage springs. These hygrophilic species include nematodes, gastropods, oligochaetes, arachnids, woodlice and insects, or these places serve as their temporary refuges (Sivec 1982; Novak \& Giribet 2006).

\section{DISCUSSION}

What environmental factors were important in the initial colonization of the hypotelminorheic?

The temperature records of seepage springs, relative to nearby surface habitats, show a consistent pattern of reduced variability. In particular, the extremes of temperature in seepage springs are reduced. This suggests that these habitats may have served as a refuge during periods of climate change. The clay of seepage springs retains water, and some stygobiotic species burrow into clay in response to drying (Holsinger \& Dickson 1977). In addition, the hypotelminorheic is a refuge from predators. The spaces of the hypotelminorheic are generally not large enough to allow for predators, they are hydrologically isolated, and visually oriented predators would be unable to locate prey in any hypotelminorheic habitat.

The barriers to colonization of caves are generally held to be the lack of light, reduced levels of available organic carbon, and the lack of daily cycles to allow for calibration of the circadian clocks. Evolution of eyelessness and other features associated with subterranean life may have been facilitated in the case of hypotelminorheic species because colonists are not as constrained by reduced resource availability or the lack of daily and seasonal cues, and are only constrained by the absence of light.

How did hypotelminorheic species colonize these spatially isolated habitats?

The presence of stygobiotic species with the typical morphological features of loss of eyes and pigment in the hypotelminorheic was unexpected. A frequent explanation for their presence was that they were accidental, or at least that hypotelminorheic were not their primary habitat. But, the hypotelminorheic fauna is often separated both vertically and laterally from any other groundwater habitat. For example, in the lower Potomac River study area, the nearest known caves are $50 \mathrm{~km}$ away, and the habitats themselves are perched at least $20 \mathrm{~m}$ from permanent groundwater. It is possible that the hypotelminorheic fauna is directly connected with a hypogean fauna of spring runs and small streams. How- ever, intensive sampling of these habitats yielded only an occasional stygobiotic individual (Culver \& Šereg 2004).

Given this spatial separation, it is much more plausible that hypotelminorheic habitats in the lower Potomac River were invaded directly from surface habitats. One possible reason for why animals invade hypotelminorheic habitats is that the temperature extremes are truncated, enabling in this way animals to avoid temperature extremes. Such populations initially isolated in hypotelminorheic habitats would not face a particularly extreme environment, except for the absence of light.

In other regions, the distance between hypotelminorheic and deep subterranean habitats is not nearly as great as it is in the lower Potomac River. For example, the hypotelminorheic sites on Nanos Mountain are within a few $\mathrm{km}$ of caves. Some species found in the hypotelminorheic, such as Niphargus stygius, which is extremely photophobic (Simčič \& Brancelj 2007; pers. observ.), may have invaded from below.

Are there distinctive morphological or physiological features that characterize species from hypotelminorheic habitats, just as there are distinctive features that distinguish subterranean species from surface dwelling species?

Culver et al. (2010) looked for morphological similarities and differences in body size and relative antennal length for species of the subterranean amhipod genus Stygobromus occurring in deep subterranean habitats (caves and phreatic waters) and in shallow subterranean habitats (epikarst and seepage springs). They argued that size itself was not necessarily a troglomorphic trait, but was dependent on the size of the habitat spaces rather than on subterranean life in general. Analyzing the morphology of the type series for each species, they found that there were significant size differences among species in different subterranean habitats, but that the size of hypotelminorheic species did not differ from that of cave stream species. They also found no differences in relative antennal length for either the number of flagellar segments or the length of the peduncle of the first an- 
tennae. The lack of differences in relative antennal length and size between cave and hypotelminorheic species can be attributed to similar selection pressures in the two habitats (Culver et al. 2010). A more detailed analysis, especially with corrections for phylogenetic relatedness need to be done. As of yet, no distinctive morphological features of hypotelminorheic species, even if this distinctiveness is a morphology intermediate between cave and surface species, have yet been found.

Culver and Poulson (1971) studied Stygobromus tenuis potomacus, found it in hypotelminorheic habitats in the Middle Atlantic region of the United States (Culver et al. 2012). Its standard metabolic rate (SMR) was intermediate $(2.1 \pm 0.6 \mu \mathrm{g} \mathrm{O} / \mathrm{g} / \mathrm{hr})$ between that of two other subterranean Stygobromus - S. emarginatus and S. spinatus. Both of these species are primarily epikarst species, although $S$. emarginatus can also be abundant in small cave streams. Thus there seems to be no overall difference between species from epikarst and hypotelminorheic habitats in metabolic rate.

\section{Future Questions}

The question of whether hypotelminorheic habitats are "evolutionary ecotones", i.e., staging grounds for adaptation to deeper, more extreme subterranean environments remains unanswered. There are at least two components to finding this answer. The first requirement is a phylogeny for lineages with both hypotelminorheic and deep subterranean taxa, and analysis of the relative position of these taxa in the resulting tree. The second requirement is a detailed morphometric analysis of the differences between the two groups. The question is not if all hypotelminorheic species give rise to deep subterranean species. They certainly do not because some of them, such as hypotelminorheic species occurring in unconsolidated coastal plain sediments, are geographically distant from any deep subterranean habitat. Rather the question is whether most or all deep subterranean species have hypotelminorheic or other shallow subterranean habitat ancestors. Resolution of this question would be a major step forward in the understanding of adaptation to subterranean life.

While a variety of hypotelminorheic and hypotelminorheic-like habitats occur, we do not think that an elaboration of terms is useful, and the focus should be on the ecological and evolutionary question raised above.

\section{ACKNOWLEDGEMENTS}

This paper was modified and adapted from a chapter on "Seepage Springs and the Hypotelminorheic Habitat" for a book by Culver and Pipan, Shallow Subterranean Habi- tats. Ecology, Evolution, and Conservation, to be published by Oxford University Press.

\section{REFERENCES}

Chapman, P., 1993: Caves and cave life.- Harper Collins, pp. 216, London.

Culver, D.C. \& S.M. Chesnut, 2006: Groundwater amphipods of the George Washington Memorial Parkway. Report to George Washington Memorial Parkway, National Park Service.

Culver, D.C, Holsinger, J.R., Christman, M.C., \& T. Pipan, 2010: Morphological differences among eyeless amphipods in the genus Stygobromus dwelling in different subterranean habitats.- Journal of Crustacean Biology, 30, 68-74.
Culver, D.C., Holsinger, J.R., \& D.J. Feller, 2012: The fauna of seepage springs and other shallow subterranean habitats in the mid-Atlantic Piedmont and Coastal Plain.- Northeastern Naturalist, 19 (Monograph 9), 1-42.

Culver, D.C. \& T. Pipan, 2008: Superficial subterranean habitats - gateway to the subterranean realm?.Cave and Karst Science, 35, 5-12.

Culver, D.C. \& T. Pipan, 2011: Redefining the extent of the aquatic subterranean biotope - shallow subterranean habitats.- Ecohydrology, 4, 721-730.

Culver, D.C., Pipan, T. \& S. Gottstein, 2006: Hypotelminorheic - a unqiue freshwater habitat.- Subterranean Biology, 4, 1-8. 
Culver, D.C. \& T.L. Poulson, 1971: Oxygen consumption and activity in closely related amphipod populations from cave and surface habitats.- American Midland Naturalist 85, 74-84.

Culver, D.C. \& I. Šereg, 2004: Kenk's Amphipod (Stygobromus kenki) and other amphipods in Rock Creek Park, Washington, D.C. Report to Rock Creek Park, National Park Service, Washington, DC. USA.

Eamus, D. \& R. Froend, 2006: Groundwater-dependent ecosystems.- Australian Journal of Botany, 54, 91237.

Fišer, C., Keber, R., Kereži, V., Moškrič, A., Palandančić, A., Petkovska, H., Potočnik, H. \& B. Sket, 2007: Coexistence of species of two amphipod genera: Niphargus timavi (Niphargidae) and Gammarus fossarum (Gammaridae).- Journal of Natural History, 41, 2641-2651.

Fišer, C., Konec, M., Kobe, Z., Osanič, M., Gruden, P. \& H. Potočnik, 2010: Conservation problems with hypotelminorheic Niphargus species (Amphipoda: Niphargidae).- Aquatic Conservation: Marine and Freshwater Ecosystems, 20, 602-604.

Fong, D.W. \& K.E. Kavanaugh, 2010: Population dynamics of the stygobiotic amphipod crustacean Stygobromus tenuis potomacus and isopod crustacean Caecidotea kenki at a single hypotelminorheic habitat over a two-year span.- In: Moškrič, A. \& P. Trontelj (eds.), ICSB International Conference on Subterranean Biology, 2010 Abstract Book, pp. 22-23, Postojna, Slovenia.

Gibert, J., 1991: Groundwater systems and their boundaries: conceptual framework and prospects in groundwater ecology.- Verhaltlungen der Internationalen Vereinigung für Theoretische und Angewandte Limnologie, 24, 1605-1608.

Ginet, R. \& V. Decu, 1977: Initiation à la biologieal 'écologie souterraines. J-P Delarge, Paris.

Gottstein Matočec, S., et al., 2002: An overview of the cave and interstitial biota of Croatia.- Natura Croatica. Croatian Natural History Museum, pp. 112, Zagreb, Croatia.

Hahn, H., 2009: A proposal for an extended typology of groundwater habitats.- Hydrology Journal,17, $77-81$.

Holsinger, J.R., 1967: Systematics, speciation, and distribution of the subterranean amphipod genus Stygonectes (Gammaridae). Bulletin of the U.S. National Museum, 259, 1-176.

Holsinger, J.R., 1978: Systematics of the subterranean amphipod genus Stygobromus (Crangonyctidae), Part II: species of the eastern United States.- Smithsonian Contributions to Zoology, No. 266., pp. 144.
Holsinger, J.R. \& G.W. Dickson, 1977: Burrowing as a means of survival in the troglobitic amphipod crustacean Crangonyx antennatus Packard (Crangonyctidae).- Hydrobiologia, 54, 195-199.

Juberthie, C., 2000: The diversity of the karstic and pseudokarstic hypogean habitats in the world.- In: Wilkens, H., Culver, D.C. \& W.F. Humphreys (eds.), Subterranean ecosystems. Elsevier, pp. 17-40, Amsterdam, The Netherlands.

Keeley, J.E. \& P.H. Zedler, 1998: Characerization and global distribution of vernal pools.- In: C.C. Witham (ed.), Vernal pool ecosystems. California Native Plant Society, pp. 1-14, Sacramento, CA, USA.

Kresic, N., 2010: Types and classifications of springs.- In: Kresic, A. \& Z. Stevanovic (eds.), Groundwater hydrology of springs. Engineering, theory, management, and sustainability. Elsevier Press, pp. 31-86, Amsterdam, The Netherlands.

Lattinger, R., 1988: Ekološka diferenciranost faune podzemnih voda Medvednice [Ecological differentiation of groundwater fauna at Medvednica Mountain]. PhD Thesis. Faculty of Science, Zagreb.

Meinzer, O.E., 1923: The occurrence of ground water in the United States with a discussion of principles.U.S. Geological Survey Water-Supply Paper, No. 489, Washington, D.C.

Meštrov, M., 1962: Un nouveau milieu aquatique souterrain: le biotope hypotelminorheique.- Compte Rendus de l'Académie des Sciences, Paris, 254, 2677-2679.

Meštrov, M., 1964: Différences et relations faunistiques et écologiques entre les milieu souterrains aquatiques.- Spelunca-Mémoires, 4, 185-187.

Novak, T. \& G. Giribet, 2006: A new species of Cyphophthalmi (Arachnida: Opiliones, Sironidae) from Eastern Slovenia.- Zootaxa, 1330, 27-42.

Pavek, D., 2002: Endangered amphipods in our nation's capital.- Endangered Species Bulletin, 27, 8-9.

Simčič, T. \& A. Brancelj, 2007: The effect of light on oxygen consumption in two amphipod crustaceans-the hypogean Niphargus stygius and the epigean Gammarus fossarum.- Marine and freshwater behavior and physiology, 40, 2, 141-150.

Sivec, I., 1982: A new apterous species of Leuctra (Plecoptera: Leuctridae) from Slovenia, Yugoslavia.Aquatic Insects, 4, 89-92. 